\title{
МІЖДИСЦИПЛІНАРНА ІНТЕГРАЦІЯ ЯК УМОВА ФОРМУВАННЯ МІЖКУЛЬТУРНОÏ КОМПЕТЕНТНОСТІ В МАЙБУТНІХ ФАХІВЦІВ МОРСЬКОЇ ГАЛУЗІ
}

\author{
INTERDISCIPLINARY INTEGRATION AS A CONDITION OF \\ INTERCULTURAL COMPETENCE FORMATION OF FUTURE MARINE \\ INDUSTRY SPECIALISTS \\ Olena TISHCHENKO, \\ Senior Lecturer \\ Олена ТІЩЕНКО, \\ https://orcid.org/0000-0002-1716-332X \\ helen020882@gmail.com \\ Azov Maritime Institute of National \\ University «Odessa Maritime \\ Academy» \\ 19 Chornomorska Street, Mariupol \\ City, Ukraine, 87517 \\ Азовський морський інститут \\ Національного університету \\ «Одеська морська академія» \\ $\triangle$ вул. Чорноморська 19, \\ м. Маріуполь, Україна, 87517 \\ Original manuscript received: February 01, 2020 \\ Revised manuscript accepted: March 02, 2020
}

\section{ABSTRACT}

The interdisciplinary approach in the educational space has a considerable number of advantages that make it necessary to apply it in maritime institutions of higher education when studying the discipline "English (professional)". Possibilities of introduction of interdisciplinary integration as an important didactic condition of formation of intercultural competence of future maritime industry specialists are analyzed in the article. It is emphasized that the formation of future sailors is a consistent process of personality change in the process of mastering a complex of disciplines, aimed at developing the ability to know, describe, evaluate, transform the surrounding reality, effectively communicate with foreign language in foreign discussion activities. The article describes the implementation of the principles of professional orientation, clarity, socio-cultural and intercultural interactions within an interdisciplinary approach.

Key words: pedagogical conditions, interdisciplinary integration, didactic principles of teaching, professional competence, specialists of the maritime industry.

Постановка проблеми. Сучасні тенденції розвитку України, її прагнення до інтеграції у світовий освітній та інфрормаційний простір, стрімке зростання міжнародних контактів зумовлюють підготовку висококваліфікованих фахівців, які б були не лише професіоналами своєї справи, але також володіли іншомовною комунікативною компетентністю. Фахівцям будь-якої галузі, а особливо морської, доводиться мати справу не лише з необхідністю долати мовний, а й культурно-ментальний бар'єр між представниками різних культурних спільнот. Основні аспекти для формування міжкультурної компетентності фахівців визначені Конституцією Укоаїни, Державною національною програмою «Освіта» (Україна XXI століття), Законами «Про освіту», «Про вищу освіту», Національною доктриною розвитку освіти, указами Президента України, постановами Кабінету Міністрів. 
У галузевому стандарті вищої освіти України визначається, що нормативну основу навчання бакалаврів морських спеціальностей становлять поряд із державними актами ще й міжнародні, зокрема Міжнародна конвенція про підготовку і дипломування моряків та несення вахти, а також Кодекс з підготовки і дипломування моряків та несення вахти 3 Манільськими поправками (Галузевий стандарт вищої освіти України, 2007). Отже, дуже важливим $€$ питання підготовки кваліфікованих, конкурентоздатних, компетентних фахівців, здатних до ефективної роботи на рівні світових стандартів. Професіоналізація навчання іноземних мов висуває за головну мету підготовку фрахівця, здатного використовувати іноземну мову як інструмент профресійної діяльності й профресійного пізнання (Т. Алексєєва, Л. Ананьєва, Л.Гапоненко, І. Куліш, В. Момот, О. Полякова, Л. Романова, Г. Скуратівська та ін.). Тому цей напрям у практиці викладання іноземних мов у вищій школі можна вважати нині одним з найактуальніших.

Особливе завдання, яке стоїть перед курсантами морських вищих закладів освіти, є уміння спілкуватися англійською мовою на достатньому рівні для проходження співбесід та для успішної роботи на борту судна в складі змішаних або багатонаціональних екіпажів.

Аналіз попередніх досліджень і публікацій. Проблема формування міжкультурної компетентності фрахівців різних галузей у процесі професійної підготовки відображена в багатьох наукових дослідженнях. Розвиток студентів засобами іноземної мови вивчали Н. Бібік, $Є$. Верещагін, $€$. Вишневський, Н. Гальськова, Л. Зиндер, І. Зимня, Г. Колшанський, Н. Коряковцева, Г.Китайгородська, Ю. Кузьменко, Ю. Пасов, С. Цимбал, Л. Щерба та ін. Основним елементом професійно орієнтованого підходу до вивчення іноземної мови $є$ іншомовна комунікативна компетентність (М. Бовтенко, Н. Гаврилюк, О. Горбуненко, В. Касьянова, І. Клейман, Н. Пустовалова, О. Тарнопольський, К.Джонсон, Т. Хатчінсон, А. Уотерс та ін.). Вузько професійній підготовці моряків присвячені роботи О. Гущіна, С. Козак, С. Ситнік, В. Кудрявцевої та ін. Однак у цих працях не розглядається детально спілкування іноземною мовою як вимога до підготовки фахівців морського транспорту. У міжнародних морських документах, зокрема в конвенції ПДНВ 78/95, наголошується на необхідності наявності у вахтових помічників капітана іншомовної профресійної компетентності: «Достатне знання англійської мови, яке дозволяе вахтовому помічнику користуватися картами та іншими морськими посібниками, розуміти метеорологічну інформацію і повідомлення щодо безпеки суден та їхньої експлуатації, а також уміння ясно висловлювати свої думки під час зв'язку з іншими суднами чи берегом, умінні розуміти і використовувати Стандартний морський словник IMKO» (STCW, 1995).

Однак, попри зростання кількості публікацій, дидактичні умови формування міжкультурної компетентності майбутніх моряків ще не були предметом спеціального розгляду. Метою cmammi $\epsilon$ обґрунтувати доцільність використання міждисциплінарного підходу викладання англійської мови як однієї 3 умов фрормування міжкультурної компетентності фахівців морської галузі. 
Результати та дискусії. Володіння іноземною мовою відноситься до однієї із найбільш важливих вимог до майбутніх фахівців морської галузі. Але також треба брати до уваги, що іноді помилки в мові іноземців залишаються поза увагою представників носіїв мови, а міжкультурні непорозуміння можуть бути набагато більш уразливими, іноді викликаючи міжкультурні конфлікти.

Перш ніж визначити комплекс дидактичних умов, що сприяють формуванню мовної особистості майбутніх моряків, конкретизуємо, як у науці трактують поняття «умова» та «дидактична умова».

В українському академічному тлумачному словнику сутність поняття «умова» визначається як необхідна обставина, яка робить можливим здійснення, створення, утворення чого-небудь або сприяє чомусь (Словник української мови, 1979: 441). У фрілософській науці поняття "умова» розглядається як категорія, у якій відображаються універсальні по відношенню до тих фракторів, завдяки яким вона виникає та існує (Философский энциклопедический словар, 1983).

Поняття «дидактична умова» вважається сукупністю об‘єктивних можливостей змісту освіти, методів, організаційних форм, що забезпечують успішне досягнення поставленої мети.

Згідно з міжнародними стандартами підготовка компетентного фахівця морської галузі визначається, насамперед, рівнями сформованості його знань та вмінь з усіх дисциплін. До циклу гуманітарних дисциплін відноситься «Англійська мова (за професійним спрямуванням)». Компетентності фрахівця морського профрілю, на думку авторів А. Вілла, Х. Гонсалес, О. Аузменді, Х. Бензанілли, Д. Пола Лакі та Р.Вагенаара, «є поєднанням властивостей (по відношенню до знань та їх застосування, навичок, умінь та обов'язків), які описують рівень або ступінь, до якого особа здатна виконувати їх».

На основі опрацювання літератури, опитування експертів (викладачів АМІ НУ «ОМА») дійшли висновку, що важливою дидактичною умовою формування мовної особистості курсантів (студентів) $\epsilon$ забезпечення міждисциплінарної інтеграції, що сприяє ефективному засвоєнню комплексу знань з різних дисциплін як інтегрованої цілісності, а не набору окремих складників. До того ж реалізація міждисциплінарної інтеграції одночасно мотивує курсантів і допомагає із засвоєнням знань, формуванням умінь і навичок набувати цінностей, досвіду.

Отже, висвітлимо суть поняття «інтегрованого навчання». У Великому тлумачному словнику інтеграція - це «доцільне об'єднання та координація дій різних частин цілісної системи» (В. Бусел, 2005). Американський педагог Дж. Гіббоне висловлював думку, що інтегрувати - це поєднувати частини систем таким чином, щоб результат об'єднання в сумі перевершував їхнє значення до взаємодії. Таким чином, інтеграція - це процес взаємодії, об'єднання, взаємовпливу, взаємопроникнення, взаємозближення, відновлення єдності двох або більше систем (у нашому випадку - професійних), результатом якого $є$ утворення нової цілісної системи, яка набуває нових властивостей та взаємозв'язків між оновленими елементами системи. 
Н. Попова визначає три рівні інтегративної основи навчання іноземної мови в закладах вищої освіти - за мірою ускладнення цього процесу:

1 рівень - фрормування міждисциплінарних зв'язків іноземної мови з іншими дисциплінами, зокрема фахового спрямування;

2 рівень - взаємопов'язане навчання різних видів мовленнєвої діяльності (наприклад, читання та говоріння);

3 рівень - використання в освітньому процесі спеціально підібраних аутентичних комплексів інноваційного спрямування (візуальних, аудіальних тощо), що підвищують мотивацію до вивчення іноземної мови (Н.Попова, 2011).

Що стосується практичної реалізації міждисциплінарної інтеграції, Н. Попова визначає такі підходи:

- текстологічний, який безпосередньо передбачає читання професійно орієнтованого тексту та його аналіз;

- аудиторний, який базується на залученні групової форми навчання. Тобто, кожна група курсантів (студентів) отримує окреме завдання, сумісно вирішуючи певну професійну проблему чи використовуючи мережу Інтернет для пошуку потрібної інформації, що максимально наближує їх до реальної професійної ситуації на борту судна. Цей підхід передбачає також фрорму дискусії та інтерактивні методи навчання.

Інтегроване заняття 3 англійської мови (за професійним спрямуванням) дає багато освітніх переваг. По-перше, англійська мова стає засобом пізнання та здобуття нової інформації. По-друге, формуються та розвиваються здібності курсантів (студентів) щодо їх майбутньої професійної діяльності. По-третє, створюються умови для застосування знань з профільних дисциплін у навчанні англійської мови, що сприяє професійному розвитку; підвищується рівень вмотивованості майбутніх фахівців морської галузі до професії та до вивчення англійської мови.

М. Шмір вказує, що систематичне використання міждисциплінарної інтеграції в освітньому процесі позитивно змінює сфреру застосування знань та вмінь, сприяє формуванню широких пізнавальних інтересів. Навчальні зв'язки іноземної мови з іншими дисциплінами носять інформаційний та фактичний характер; тобто, всебічне висвітлення їх на рівні фрактів, подій сприяє узагальненню та систематизації знань, підвищує конкурентоспроможність та мобільність майбутніх фахівців (М.Шмир, 2011: 221-224).

Ураховуючи специфіку викладання іноземної мови в морських закладах вищої освіти, вважаємо за доцільне додати також такі переваги інтеграції: підготовка нової теми сприяє співпраці між викладачами гуманітарних та професійних дисциплін, об'єднує їхні зусилля, допомагає розглянути подібні теми з різних точок зору, уникаючи простого дублювання матеріалу під час вивчення різних дисциплін; міждисциплінарні теми та ситуації дають можливість для викладача іноземної мови оновити наявний зміст навчання; дібрати більш широкий спектр соціальних ролей, мовного та мовленнєвого матеріалу для формування в курсантів (студентів) іншомовної комунікативної компетентності; підготовка заняття на основі міждисциплінарного підходу 
сприяє розвитку творчого мислення, розробці нових цікавих вправ, стимулює професійне зростання викладачів.

Неважко помітити, що ситуації в іншомовному реальному режимі вимагають від курсантів (студентів) морських закладів вищої освіти не лише знання конкретних правил поведінки, готового алгоритму дій і простого відтворення такої поведінки із представниками іншої мови та культури, а й здатності правильно дати оцінку ситуації, спроєктувати свої дії та поведінку для подальшого взаєморозуміння зі співрозмовником, при цьому використовуючи соціокультурний особистісний досвід. Так, майбутні фахівці морської галузі мають бути готовими до міжкультурного спілкування із представниками інших країн, до вибору відповідного стилю соціокультурної поведінки та здатними до підтримання діалогу, при цьому вміти використовувати та знаходити нестандартні рішення в незнайомих соціокультурних ситуаціях.

Процес упровадження міждисциплінарної інтеграції заснований на загальнодидактичних та специфічних принципах. Сформулюємо основні з них.

1. Принцип профресійної спрямованості. Завдяки цьому принципу на заняттях з англійської мови (за професійним спрямуванням) розглядаються теми дисциплін професійної та практичної підготовки майбутніх моряків, робиться акцент на ситуаціях, близьких до реальних. Наприклад: ви знаходитесь на борту судна і раптово сталося займання на навігаційному мостику; потрібно розповісти англійською мовою порядок дій у цій ситуації, а також визначити обладнання, яке буде використане. Усе це сприяє врахуванню професійних інтересів курсантів (студентів), оволодінню ними мовою спеціальності, особливостями спілкування фахівців i, як наслідок, успішному оволодінню обраною професією.

2. Принцип наочності в межах міждисциплінарного підходу передбачає використання на занятті з англійської мови схем, фотографій, моделей тощо, які демонструють зв'язки різних дисциплін.

3. Соціокультурний принцип забезпечує формування в курсантів соціокультурної компетентності, тобто сукупності знань про матеріальну й духовну культуру народів, соціокультурні стереотипи мовленнєвого спілкування. Реалізація цього принципу може відбуватися шляхом дозованого включення до занять додаткових фонових знань та мовних засобів, які мають їм відповідати та за змістом і ступенем складності узгоджуються з інформацією підручників, ураховують рівень володіння студентів мовою.

4. Принцип міжкультурної взаємодії. Реалізація цього принципу відбуватиметься шляхом включення зразків мовлення представників різних країн, американського та британського варіанту англійської мови та вправ, які передбачають аналіз стандартів комунікативної поведінки під час англомовного спілкування, відмінності культур фахівців морської галузі різних країн тощо.

Інтеграція в процесі навчання англійської мови (за професійним спрямуванням) відповідає одній з основних тенденцій сучасного розвитку вищої освіти. Англійська мова в морському вищому закладі освіти повинна вивчатися нерозривно з фаховими дисциплінами, забезпечуючи 
реалізацію моделі «інститут - виробництво» (В. Луговий, 2009: 7-12).

$$
\text { Реалізація принципів міждисциплінарної інтеграції }
$$

продемонстровано на прикладі навчання курсантів кафедри «Навігації і управління судном» Азовського морського інституту Національного університету «Одеська морська академія». Наведемо декілька прикладів в таблиці:

\begin{tabular}{|c|c|c|}
\hline $\begin{array}{c}\text { Назва навчальної } \\
\text { дисципліни }\end{array}$ & Тема & $\begin{array}{c}\text { Тема з англійської мови (за } \\
\text { профресійним спрямуванням) }\end{array}$ \\
\hline $\begin{array}{l}\text { Стандарти } \\
\text { Міжнародної } \\
\text { морської } \\
\text { організації }\end{array}$ & $\begin{array}{l}\text { Конвенції ІМО } \\
\text { Протипожежний захист, } \\
\text { виявлення і гасіння пожежі } \\
\text { Рятувальні засоби ГМССБ }\end{array}$ & $\begin{array}{l}\text { STCW95 Competences / } \\
\text { Maritime Education and } \\
\text { English } \\
\text { The Location and Purpose of } \\
\text { Safety Equipment } \\
\text { Emergency situations onboard }\end{array}$ \\
\hline $\begin{array}{l}\text { Практика несення } \\
\text { штурманської } \\
\text { вахти }\end{array}$ & $\begin{array}{l}\text { Безпека на навігаційній вахті. } \\
\text { Погода на переході } \\
\text { Ведення суднового журналу. } \\
\text { Суднова бібліотека }\end{array}$ & $\begin{array}{l}\text { GMDSS and ship-to-shore } \\
\text { communications and making } \\
\text { entries into the log book. } \\
\text { Weather conditions and } \\
\text { weather forecasts }\end{array}$ \\
\hline $\begin{array}{l}\text { Глобальний } \\
\text { морський зв'язок } \\
\text { для пошуку та } \\
\text { рятування }\end{array}$ & $\begin{array}{l}\text { Радіозв'язок і організація } \\
\text { служби на морі } \\
\text { Система цифрового } \\
\text { вибіркового виклику } \\
\text { Передача сигналу тривоги у } \\
\text { випадку лиха }\end{array}$ & $\begin{array}{l}\text { Communication at sea } \\
\text { GMDSS } \\
\text { VHF communication regarding } \\
\text { distress and urgency } \\
\text { messages }\end{array}$ \\
\hline $\begin{array}{l}\text { Міжнародні } \\
\text { правила } \\
\text { попередження } \\
\text { зіткнення суден }\end{array}$ & $\begin{array}{l}\text { Вогні і знаки. Пр.20-36 } \\
\text { Небезпека зіткнення та дії } \\
\text { для запобігання зіткнень. } \\
\text { Пр.7-8 }\end{array}$ & $\begin{array}{l}\text { Lights, shapes and sound } \\
\text { signals } \\
\text { Dangers. The principles of the } \\
\text { watchkeeping and Collision } \\
\text { Regulations }\end{array}$ \\
\hline Навігація та лоція & $\begin{array}{l}\text { Карта і картографічна } \\
\text { проєкція. Масштаби }\end{array}$ & Navigational aids. Charts. \\
\hline $\begin{array}{l}\text { Маневрування і } \\
\text { управління } \\
\text { судном }\end{array}$ & $\begin{array}{l}\text { Суднові навчання } \\
\text { Управління судном при } \\
\text { прийомі лоцмана } \\
\text { Підготовка судна до } \\
\text { швартових операцій } \\
\text { Підготовка якоря до віддачі } \\
\text { на різних глибинах }\end{array}$ & $\begin{array}{l}\text { Ship drills and trainings } \\
\text { Pilotage and pilots } \\
\text { Berthing and unberthing. } \\
\text { Anchoring and anchorages. }\end{array}$ \\
\hline
\end{tabular}

Висновки. Професія судноводія (або іншого фахівця морської галузі) вимагає комплексу (лінгвістичних, екстралінгвістичних, загальнокультурних) знань, а також тих, які необхідні для оволодіння майбутньою професією. Це зумовлює впровадження в освітній процес провідної педагогічної умови формування мовної особистості майбутніх фахівця морської галузі - забезпечення міждисциплінарної інтеграції.

Інтегративний підхід у морських закладах вищої освіти здійснюється за такими напрямами: міждисциплінарна інтеграція, інтегрування теоретичного навчання та практичної (виробничої) підготовки, інтегрування набутих знань і майбутньої профресійної діяльності тощо. Міждисциплінарний 
підхід сприяє реалізації всіх дидактичних принципів навчання, стимулює викладача до оновлення змісту навчання, збагачення його цікавими та актуальними міждисциплінарними темами, новими соціальними ролями та комунікативними ситуаціями.

Перспективи подальшого дослідження полягають у розробці методичного забезпечення для реалізації міждисциплінарного підходу.

\section{Література}

1.Великий тлумачний словник сучасної української мови: 250000 / Уклад. В. Бусел. - Київ; Ірпінь, 2005. - Т. VIII.- 1728 с.

2.Луговий В.І. Компетентності та компетенції: поняттєво-термінологічний дискурс / В.І. Луговий // Вища освіта України. Вип. «Педагогіка вищої школи: методологія, теорія, технології». - 2009. - №3. - С.7-12.

3.Попова Н.В. Междисциплинарная парадигма как основа формирования интегративных компетенций студентов многопрофильного вуза (на примере дисциплины Иностранный язык): автореф. дис. на соиск. ст. д.п.Н. / Н.В. Попова.СПб., 2011. - 50 с.

4. Словник української мови: в 11 томах. Т. 10. - К., 1979. - С. 441.

5. Философский энциклопедический словарь.- М.: Сов. энцикл., 1983. -840 с.

6. Шмир М.Ф. Міжпредметний підхід у формуванні діяльнісної компетенції студентів у вивченні німецької мови / М. Ф. Шмир // Педагогічний альманах: збірник наук. праць.- Херсон, 2011. - Вип. 12. - Ч. 2. - С. 221-224.

7.STCW. International Convention on Standards of Training, Certification and Watchkeeping for Seafarers, 1995 (amended in 2010). - L. - IMO, 2012.- 346 p.

8. Галузевий стандарт вищої освіти України [Електронний ресурс]. - Режим доступу: http://osvita.ua/doc/files/news/31/3158/MON 897 07.doc

9. Методичні розробки вчителів С3Н3 №2 м. Чернігова [Електронний pecypc]. - Режим доступу: http://metod-skarb.at.ua/komunikativno-kognitivnij pidkhid u vivchenni im-1.doc

\section{References}

1. Busel V. (2005) Velykyi tlumachnyi slovnyk suchasnoi ukrainskoi movy: 250000 T. VIII [Great Explanatory Dictionary of Modern Ukrainian Language: 250000 Vol. VIII]. Kyiv; Irpin [in Ukrainian].

2. Filosofskii entsiklopedicheskii slovar (1983) [Philosophical Encyclopedic Dictionary]. Moscow: Sov. entsykl. [in Russian].

3. Haluzevyi standart vyshchoi osvity Ukrainy [Industry Standard of Higher Education of Ukraine]. Retrieved from http://osvita.ua/doc/files/news/31/3158 /MON 897 07.doc [in Ukrainian].

4. Luhovyi V. (2009) Kompetentnosti ta kompetentsii: poniattievo-terminolohichnyi dyskurs [Competences: Terminological Discourse] Vyshcha osvita Ukrainy, 3 «Pedahohika vyshchoi shkoly: metodolohiia, teoriia, tekhnolohii», pp. 7-12 [in Ukrainian].

5. Metodychni rozrobky vchyteliv SZNZ №2 $\mathrm{m}$. Chernihova [Methodical Recomendations of Teachers of Educational Center 2 in Chernihiv]. Retrieved from http://metod-skarb.at.ua/komunikativno-kognitivnij pidkhid u vivchenni im-1.doc [in Ukrainian].

6. Popova N. (2011) Mezhdistsiplinarnaia paradigma kak osnova formirovaniia integrativnykh kompetentsii studentov mnogoprofilnogo vuza (na primere distsipliny Inostrannyi yazyk): avtoref. dis. na soisk. st. d.p.n. / N.V. Popova [Interdisciplinary Paradigm as Basis for Formation of Integrative Competencies of Multidisciplinary University Students (on Example of Foreign Language Discipline): Author. Dis. for job. Ph.D.]. St. Petersburg [in Russian].

7. Shmyr M. (2011) Mizhpredmetnyi pidkhid u formuvanni diialnisnoi 
kompetentsii studentiv u vyvchenni nimetskoi movy [Cross-Curricular Approach in Developing Students' Business Competence in Learning German] Pedahohichnyi almanakh: zbirnyk nauk. prats 12. Kherson, pp. 221-224 [in Ukrainian].

8. Slovnyk ukrainskoi movy: v 11 tomakh (1979) [Dictionary of Ukrainian Language: in 11 Volumes] T. 10. Kyiv, p. 441 [in Ukrainian].

9. STCW. International Convention on Standards of Training, Certification and Watchkeeping for Seafarers 1995, amended in 2010 (2012). London [in English].

\section{АНОТАЦІЯ}

Міждисциплінарний підхід в освітньому просторі має значну кількість переваг, які зумовлюють необхідність його застосування в морських закладах вищої освіти під час вивчення дисципліни «Англійська мова (за професійним спрямуванням)». У статmі проаналізовано можливості впровадження міждисциплінарної інтеграції як важливої дидактичної умови формування міжкультурної компетентності майбутніх фрахівців морської галузі. Акцентовано увагу, що це послідовний процес зміни особистості в процесі опанування комплексу дисциплін, спрямований на розвиток здатностей пізнавати, описувати, оцінювати, перетворювати навколишню дійсність, ефрективно спілкуватися засобами іноземної мови в іншомовній дискусійній діяльності. У роботі описано реалізацію принципів професійної спрямованості, наочності, соціокультурної та міжкультурної взаємодій у межах міждисциплінарного підходу.

Ключові слова: педагогічні умови, міждисциплінарна інтеграція, дидактичні принципи навчання, професійна компетентність, фрахівці морської галузі. 